\title{
Effect of wheat and Miscanthus straw biochars on soil enzymatic activity, ecotoxicity, and plant yield**
}

\author{
Monika Mierzwa-Hersztek ${ }^{1}$, Krzysztof Gondek ${ }^{1}$, Agnieszka Klimkowicz-Pawlas ${ }^{2}$, and Agnieszka Baran ${ }^{1}$ \\ ${ }^{1}$ Department of Agricultural and Environmental Chemistry, University of Agriculture in Kraków, \\ al. Mickiewicza 21, 31-120 Kraków, Poland \\ ${ }^{2}$ Department of Soil Science Erosion and Land Protection, Institute of Soil Science and Plant Cultivation-State Research Institute, \\ Czartoryskich 8, 24-100 Puławy, Poland
}

Received October 28, 2016; accepted June 2, 2017

\begin{abstract}
A b s t r a c t. The variety of technological conditions and raw materials from which biochar is produced is the reason why its soil application may have different effects on soil properties and plant growth. The aim of this study was to evaluate the effect of the addition of wheat straw and Miscanthus giganteus straw $\left(5 \mathrm{t} \mathrm{DM} \mathrm{ha}^{-1}\right.$ ) and biochar obtained from this materials in doses of 2.25 and $5 \mathrm{t} \mathrm{DM} \mathrm{ha}{ }^{-1}$ on soil enzymatic activity, soil ecotoxicity, and plant yield (perennial grass mixture with red clover). The research was carried out under field conditions on soil with the granulometric composition of loamy sand. No significant effect of biochar amendment on soil enzymatic activity was observed. The biochar-amended soil was toxic to Vibrio fischeri and exhibited low toxicity to Heterocypris incongruens. Application of wheat straw biochar and $M$. giganteus straw biochar in a dose of $5 \mathrm{t}$ DM ha ${ }^{-1}$ contributed to an increase in plant biomass production by 2 and $14 \%$, respectively, compared to the soil with mineral fertilisation. Biochars had a more adverse effect on soil enzymatic activity and soil ecotoxicity to $H$. incongruens and $V$. fischeri than non-converted wheat straw and $M$. giganteus straw, but significantly increased the grass crop yield.

K e y w o r d s: biochar, soil, enzymatic activity, bioassays, crop yield
\end{abstract}

\section{INTRODUCTION}

Fertilisation of soil with organic materials significantly affects the quality of soil, which not only is important for its productive function, but also plays role in the ecosystem (Fekete et al., 2012; Schmidt et al., 2011). Modern agricultural holdings aiming at maximising their production, generate significant amounts of agricultural by-products (e.g. straw), whose management is increasingly difficult. Worse still, the problem is compounded by the increasing acreage of cereal cultivation and the introduction of litter-

*Corresponding author e-mail: monika6_mierzwa@wp.pl

**This work was financed by the Ministry of Science and Higher Education of the Republic of Poland. free systems in livestock farming (Wu et al., 2013; Zhang et al., 2016). An alternative allowing a more effective use of nutrients contained in these materials is their thermal conversion to biochar. Pyrolysis temperature and feedstock type (e.g. crop and forest residues, animal manure, sewage sludge, energy crops) are the most important factors in determining the possibilities of using biochars (Sun et al., 2014). Due to their diversified properties, biochars have become widely used not only in environmental protection (improvement of the quality of soil, climate change mitigation, waste management, remediation of contaminated soil, animal feed), but also in many industries (energy production, an ingredient of cosmetics, and a component of building materials and clothing) (Lehmann and Joseph, 2015; Sun et al., 2014).

Aromatic carbon compounds formed during biomass pyrolysis are resistant to microbial decomposition, and hence the application of biochar increases the pool of carbon in the soil (Cheng et al., 2006; Lehmann and Joseph, 2015). Song and Guo (2012) found that, for agricultural purposes, the temperature of material pyrolysis should not exceed $300^{\circ} \mathrm{C}$, since the resulting biochars exhibit significantly higher cation exchange capacity and increased content of humic acids. In addition, biochars produced at a temperature above $300^{\circ} \mathrm{C}$ contain a much smaller quantity of aliphatic carbon compounds and functional groups, which may significantly reduce the effectiveness of these materials in improving soil quality. This is due to dehydration and decarboxylation processes taking place during the thermal conversion of biomass, which lead to compaction of aromatic carbon structures. The theory is confirmed by

(C) 2017 Institute of Agrophysics, Polish Academy of Sciences 
the results of laboratory tests performed by Gondek et al. (2014). It is important to bear in mind that thermal conversion of materials may have radically different effects. On the one hand, pyrolysis can lead to decomposition of organic compounds, and on the other, it results in synthesis of highly condensed aromatic structures that may produce other aromatic-structure compounds or increase their content (Busch et al. 2013). As demonstrated by Gondek et al. (2016), the pyrolysis of organic materials at $300^{\circ} \mathrm{C}$ increased the content of 2- and 3-ring hydrocarbons. However, the conversion of organic materials at $600^{\circ} \mathrm{C}$ reduced the content of 4- and 5-ring hydrocarbons in the obtained biochars.

Biochar is not biologically inert and, when added to the soil, undergoes biphasic mineralisation therein. Firstly, only labile and volatile biochar compounds are mineralised, and then, slow decomposition of aromatic compounds takes place (Ameloot et al., 2015). Consumption of unstable nutrients by soil microorganisms affects numerous biological parameters of the soil, such as enzymatic activity (Kuzyakov et al., 2009; Mierzwa-Hersztek et al., 2016; Paz-Ferreiro et al., 2014), microbial biomass (Zavalloni et al., 2011), and diversity of microorganisms (Lehmann and Joseph, 2015). Ameloot et al. (2015) and Alburquerque et al. (2013) suggested that biochar is an excellent source of nitrogen available not only to microorganisms, but also to plants. This is mainly due to changes in the soil $\mathrm{pH}$ and $\mathrm{C}: \mathrm{N}$ ratio, which play an important role in the stimulation of microorganisms involved in the mineralisation of organic matter and nitrogen transformations.

Enzymatic activity and ecotoxicity are considered as sensitive and effective bio-indicators of changes in soil quality. These tests are very important, especially in the assessment of the impact of organic materials with different chemical properties (such as biochar) on soil (Paz-Ferreiro et al., 2014). Although ecotoxicity tests are much more sensitive to changes in environmental conditions compared to soil chemical and physical indicators, their interpretation is sometimes more complex and difficult. The presence of potentially toxic heavy metals and polycyclic aromatic hydrocarbons (PAHs) in biochar as well as its usually strong alkaline reaction can pose a serious threat to the soil quality and its biological life in particular. Studies of Cui et al. (2013) and Yang et al. (2016) clearly show that there is a close correlation between the concentration of heavy metals, $\mathrm{pH}$, and enzymatic activity of soil. Also research of Wu et al. (2013) and our previous study (Mierzwa-Hersztek et al., 2016) indicated that the use of biochar obtained from various feedstocks may have different effects on enzymatic activity and ecotoxicity of soil. This is usually a result of the sum of synergistic and/or antagonistic responses of soil to the addition of organic materials before and after thermal conversion. However, it should be noted that the studies of the effects of biochar on soil biota have received less attention compared to the assessment of the effect of biochar on the chemical pro- perties of soil (Lehmann et al., 2011). Most studies on the soil biology after the application of biochar showed significant changes in the population of microorganisms and the activity of soil enzymes. As reported by Lehmann et al. (2011), this is mainly due to biochemical changes in nutrients. Both chemical (sorption capacity, $\mathrm{pH}$, mineral content) and physical properties of biochar significantly influence relations between the soil and living organisms. Observations of microbial dynamics lead to the conclusion of a possible improved resource use due to co-location of various resources in and around biochars. Sorption and thereby inactivation of growth-inhibiting substances likely play a role in increased abundance of soil biota. No evidence exists so far for direct negative effects of biochars on plant roots. In the short term, the release of a variety of organic molecules from fresh biochar may be in some cases responsible for increases or decreases in the abundance and activity of soil biota (Lehmann et al., 2011). The application of biochar to the soil can significantly influence crop yielding due to the improvement of physical (soil structure), chemical (nutrient availability), and biological (enzymatic activity) properties of soil.

The aim of the study was to assess the effect of the addition of wheat straw and Miscanthus straw before and after thermal conversion on the enzymatic activity and ecotoxicity of loamy sand soil and on plant yield.

\section{MATERIALS AND METHODS}

The micro-plot experiment was carried out in April 2014 on arable land located in southern Poland $\left(50^{\circ}\right.$ $08,404^{\prime} \mathrm{N} ; 1^{\circ} 85,362^{\prime} \mathrm{E}$ ) in 3 replicates using the method of randomised blocks. The soil type was loamy sand Eutric Cambisol ( $73 \%$ sand, $15 \%$ silt and $12 \%$ clay) according to the WRB Classification (WRB, 2015). The soil was slightly acidic $\left(\mathrm{pH} \mathrm{H}_{2} \mathrm{O}=6.46, \mathrm{pH} \mathrm{KCl}=5.59\right)$ and had low carbon (9.84 $\left.\mathrm{g} \mathrm{kg}^{-1} \mathrm{DM}\right)$ and nitrogen $\left(1.28 \mathrm{~g} \mathrm{~kg}^{-1} \mathrm{DM}\right)$ contents. The scheme of the micro-plot experiment is presented in Table 1.

Due to the necessity to create comparable conditions, mineral fertilisers (N, P, K: 100, 40, and $120 \mathrm{~kg} \mathrm{ha}^{-1}$, respectively) were applied. Wheat straw, Miscanthus straw, and biochars derived from them were mixed with the soil top layer $(0-0.1 \mathrm{~m})$, and then a pasture grass mix with red clover was sown using $60 \mathrm{~kg} \mathrm{ha}^{-1}$ of seeds. Annual production of pasture grass mixture biomass was determined by mechanical harvesting (three harvests per year). The above-ground biomass from each micro-plot was collected separately. The biomass was dried to constant weight at $60^{\circ} \mathrm{C}$ and dry masses were measured.

Biochar was produced from the biomass of two plant species: Miscanthus (Miscanthus giganteus) and winter wheat (Triticum aestivum L.). Miscanthus and wheat straws were dried at ambient temperature, ground in a laboratory mill (mesh size of $4 \mathrm{~mm}$ ), and mixed to ensure homogeneity. 
T a b l e 1. Scheme of the micro-plot experiment

\begin{tabular}{cl}
\hline Treatment & Description \\
\hline MF & control soil without fertilisation \\
WS & soil with mineral fertilisers (NPK) \\
WSB I & soil + NPK + wheat straw in a dose of $5 \mathrm{t} \mathrm{DM} \mathrm{ha}^{-1}$ \\
WSB II & soil + NPK + wheat straw biochar in a dose of $2.25 \mathrm{t} \mathrm{DM} \mathrm{ha}^{-1}$ \\
MS & soil + NPK + Miscanthus straw in a dose of $5 \mathrm{t} \mathrm{DM} \mathrm{ha}^{-1}$ \\
MSB I & soil + NPK + Miscanthus straw biochar in a dose of $2.25 \mathrm{t} \mathrm{DM} \mathrm{ha}^{-1}$ \\
MSB II & soil + NPK + Miscanthus straw biochar in a dose of $5 \mathrm{t} \mathrm{DM} \mathrm{ha}^{-1}$ \\
\hline
\end{tabular}

The plant material was pyrolysed in an electric laboratory furnace (equipped with a temperature controller) at $300^{\circ} \mathrm{C}$ for 15 min under a limited supply of air (IBI, 2014). The rate of heating the combustion chamber was $10^{\circ} \mathrm{C} \mathrm{min}^{-1}$. The pyrolysis time and temperature were established on the basis of the studies of Lu et. al. (2013) and Gondek et al. (2014).

Feedstocks and biochars were ground in a laboratory mill (mesh size of $1 \mathrm{~mm}$ ) and dry matter content was determined after drying these materials at $105^{\circ} \mathrm{C}$ for $12 \mathrm{~h}$ (Jindo et al., 2012). In order to determine the total content of macroelements and trace elements, organic material samples were placed in Teflon vessels and treated with $6 \mathrm{~cm}^{3}$ of concentrated $\mathrm{HNO}_{3}$ (Suprapur $65 \%$ ) and $2 \mathrm{~cm}^{3}$ of $\mathrm{H}_{2} \mathrm{O}_{2}$. Subsequently, the materials were mineralised in a closed system using a Multiwave 3000 microwave oven manufactured by AntonPaar. The contents of macroelements and trace elements were determined by inductively coupled plasma optical emission spectrometry (ICP-OES) using Perkin Elmer Optima 7300 DV (Oleszczuk et al., 2007). Specific surface area $\left(\mathrm{S}_{\mathrm{BET}}\right)$ of organic materials as well as pore volume and diameter were determined using the multifunction accelerated surface area and porosimetry analyser ASAP 2010 (Micrometics, USA). The samples were degassed and their specific surface area $\left(\mathrm{S}_{\mathrm{BET}}\right)$ was determined by physical nitrogen adsorption using the Brunauer-Emmett-Teller equation (Barret et al., 1951).

After plant vegetation was harvested, soil samples were collected from each plot $\left(1 \mathrm{~m}^{2}\right)$ from the $0-0.1 \mathrm{~m}$ soil layer (in the second year of the experiment, 18 months after application of organic materials). The soil material for chemical and physicochemical determinations was dried and sieved through a $1 \mathrm{~mm}$ mesh. The analyses of enzymatic activity and toxicity tests were conducted in fresh soil samples.

The following properties were determined in the soil samples: $\mathrm{pH}$ with the potentiometric method in $\mathrm{H}_{2} \mathrm{O}$ and $1 \mathrm{~mol} \mathrm{dm}{ }^{-3} \mathrm{KCl}$ (soil : solution $=1: 2.5$ ), electrical conductivity (EC) - with a conductometer. The content of total carbon, nitrogen, and sulphur in the soil, feedstocks, and biochars was determined on a CNS analyser (Vario MAX Cube, Elementar Analysensysteme GmbH).

Dehydrogenase (EC 1.1.1.1) activity (DhA) was determined using the method of Casida et al. (1964), using triphenyltetrazolium chloride (TTC) as an electron acceptor. Samples were incubated at $37 \pm 2^{\circ} \mathrm{C}$ for $24 \mathrm{~h}$. Triphenylformazan (TPF) resulting from the reduction of TTC in soil was extracted with ethanol and the intensity of the red colour of the solution was measured at a wavelength of $485 \mathrm{~nm}$ on a Lambda 45 UV-VIS spectrophotometer (Perkin Elmer, USA). Urease (EC 3.5.1.5) activity (Ure) was determined with the Zantua and Bremner (1975) method, with urea as a substrate, after $18 \mathrm{~h}$ incubation at $37 \pm 2{ }^{\circ} \mathrm{C}$. Enzymatic activity of ureases was determined by colourimetry using a Backman DU 640 spectrophotometer at a wavelength of $470 \mathrm{~nm}$.

Two bioassays (Microtox ${ }^{\circledR}$ and Ostracodtoxkit F) were applied for the assessment of soil ecotoxicity. The Microtox ${ }^{\circledR}$ test utilizes the bioluminescent properties of bacteria Vibrio fischeri. 81.9\% Screening Test was applied for testing soil elutriates. The elutriates were prepared by mixing the soil with redistilled water ( shaking for $24 \mathrm{~h}$, centrifugation (10 min at 3000 r.p.m.), and filtration (Gondek et al., 2014; Mierzwa-Hersztek et al., 2016). Changes in bioluminescence were measured on a Microtox M500 Analyzer (MicrobicsCorporation, 1992) after $15 \mathrm{~min}$ of bacterial exposure to the sample. Toxicity assessment of bulk soil samples was performed using the Ostracodtoxkit F biotest. Test organism (Heterocypris incongruens) was exposed to the soil sample and after 6 days the mortality and growth inhibition of the crustacean were determined (Ostracodtoxkit, 2001). All toxicity determinations were performed in three replications. The results from both bioassays were expressed as a Percent Effect (PE\%).

Toxicity data were expressed as the percentage of the toxic effect (PE) compared to the control. Mean values were taken from each triplicate data set. The differences 
between each treatment and the control as well as between treatments were evaluated using one-way analysis of variance (ANOVA, Duncan test, $\mathrm{p} \leq 0.05$ ). Variation within treatments was determined by calculating the values of standard deviation $( \pm \mathrm{SD})$. All statistical analyses were performed using Statistica PL 12.5 software (StatSoft Inc.).

\section{RESULTS AND DISCUSSION}

Biochar $\mathrm{pH}$ and its other properties may depend on the type of feedstock, temperature, and the time of pyrolysis (Gondek et al., 2016; Lu et al., 2013). In addition to the dose, differences resulting from the $\mathrm{pH}$ value of organic materials and soil are usually the main factor contributing to changes in the soil $\mathrm{pH}$, but it is not always analogous to the desired effect. Studies of Cheng et al. (2006) revealed that biochar with a $\mathrm{pH}$ of 5.38 applied to an acidic soil $(\mathrm{pH}=4.33)$ had an alkalising effect on it. According to these authors, this was probably due to the release of acidic functional groups during the oxidation of functional groups of biochar.

The feedstocks used in our study, i.e. wheat straw (WS) and Miscanthus straw (MS), had lower $\mathrm{pH}$ and electrical conductivity (EC) values compared to the biochars produced from these materials (Table 2). The wheat straw biochar (WSB) and the Miscanthus straw biochar (MSB) demonstrated higher contents of total nitrogen, carbon, and sulphur compared to the non-pyrolysed materials. The organic matter loss during the pyrolysis contributed to an increase in the concentration of heavy metals in both biochars. The biochars had also a greater specific surface area and pore diameter (Table 2).

The application of organic materials caused no significant $(\mathrm{p} \leq 0.05)$ changes in the $\mathrm{pH}$ value compared to the MF treatment. In the second year of the experiment, a slight

T a b 1 e 2. Chemical and physical properties of feedstock and biochar obtained from wheat straw and Miscanthus straw

\begin{tabular}{|c|c|c|c|c|c|}
\hline \multirow{2}{*}{ Determination } & \multirow{2}{*}{ Units } & \multicolumn{2}{|c|}{ Feedstock (dry matter) } & \multicolumn{2}{|c|}{ Biochar } \\
\hline & & WS & MS & WSB & MSB \\
\hline $\mathrm{pH}$ in $\mathrm{H}_{2} \mathrm{O}$ & - & $5.84 \pm 0.15$ & $6.18 \pm 0.43$ & $6.52 \pm 0.60$ & $6.28 \pm 0.42$ \\
\hline $\mathrm{EC}$ & $\mu \mathrm{S} \mathrm{cm}^{-1}$ & $4.48 \pm 0.21$ & $3.23 \pm 0.45$ & $378 \pm 21$ & $345 \pm 18$ \\
\hline Dry matter & $\mathrm{g} \mathrm{kg}^{-1}$ & $952 \pm 0.2$ & $947 \pm 0.3$ & $966 \pm 2$ & $977 \pm 1$ \\
\hline Ash & $\mathrm{g} \mathrm{kg}^{-1} \mathrm{DM}$ & $59 \pm 2$ & $54 \pm 1$ & $134 \pm 5$ & $87 \pm 3$ \\
\hline $\mathrm{C}_{\text {total }}$ & & $441 \pm 2$ & $456 \pm 2$ & $628 \pm 2$ & $651 \pm 6$ \\
\hline $\mathrm{N}_{\text {total }}$ & & $7.16 \pm 0.32$ & $3.97 \pm 0.29$ & $12.4 \pm 0.36$ & $7.31 \pm 0.09$ \\
\hline $\mathrm{S}_{\text {total }}$ & & $0.95 \pm 0.21$ & $0.58 \pm 0.05$ & $2.16 \pm 0.21$ & $2.00 \pm 0.24$ \\
\hline $\mathrm{K}_{\text {total }}$ & & $4.95 \pm 0.66$ & $1.33 \pm 0.06$ & $11.9 \pm 0.29$ & $2.81 \pm 0.17$ \\
\hline $\mathrm{P}_{\text {total }}$ & & $1.04 \pm 0.05$ & $0.73 \pm 0.04$ & $1.17 \pm 0.04$ & $0.94 \pm 0.06$ \\
\hline $\mathrm{Cd}_{\text {total }}$ & $\mathrm{mg} \mathrm{kg}^{-1} \mathrm{DM}$ & $0.56 \pm 0.04$ & $0.14 \pm 0.00$ & $1.20 \pm 0.02$ & $0.31 \pm 0.03$ \\
\hline $\mathrm{Cr}_{\text {total }}$ & & $2.22 \pm 0.49$ & $1.89 \pm 0.34$ & $4.01 \pm 0.12$ & $4.29 \pm 0.25$ \\
\hline $\mathrm{Cu}_{\text {total }}$ & & $1.32 \pm 0.08$ & $1.77 \pm 0.22$ & $3.19 \pm 0.15$ & $4.14 \pm 0.31$ \\
\hline $\mathrm{Ni}_{\text {total }}$ & & $1.12 \pm 0.08$ & $0.82 \pm 0.13$ & $1.97 \pm 0.07$ & $1.78 \pm 0.12$ \\
\hline $\mathrm{Pb}_{\text {total }}$ & & $0.73 \pm 0.09$ & $1.15 \pm 0.18$ & $1.62 \pm 0.24$ & $2.44 \pm 0.29$ \\
\hline $\mathrm{Zn}_{\text {total }}$ & & $32.9 \pm 4.78$ & $14.4 \pm 4.31$ & $48.8 \pm 1.26$ & $32.0 \pm 5.22$ \\
\hline $\mathrm{S}_{\mathrm{BET}}$ & $\mathrm{m}^{2} \mathrm{~g}^{-1}$ & $0.55 \pm 0.02$ & $0.39 \pm 0.04$ & $0.67 \pm 0.09$ & $0.44 \pm 0.01$ \\
\hline Pore volume & $\mathrm{cm}^{3} \mathrm{~g}^{-1}$ & $0.0009 \pm 0.000$ & $0.0007 \pm 0.001$ & $0.0016 \pm 0.002$ & $0.0023 \pm 0.002$ \\
\hline Pore diameter & $\mathrm{nm}$ & $6 \pm 2$ & $6 \pm 1$ & $12 \pm 3$ & $23 \pm 3$ \\
\hline Maximum pore diameter & $\mathrm{nm}$ & 67 & 77 & 123 & 108 \\
\hline
\end{tabular}

\pm standard deviation, $\mathrm{n}=3$. 
T a b 1 e 3. Selected soil properties (layer 0-0.1 m) after 18 months of experiment

\begin{tabular}{|c|c|c|c|c|}
\hline \multirow{2}{*}{ Treatment } & \multirow{2}{*}{$\mathrm{pH} \mathrm{H} \mathrm{H}_{2} \mathrm{O}$} & $\mathrm{EC}$ & $\mathrm{C}_{\text {total }}$ & $\mathrm{N}_{\text {total }}$ \\
\hline & & $\left(\mu \mathrm{S} \mathrm{cm}^{-1}\right)$ & \multicolumn{2}{|c|}{$\left(\mathrm{g} \mathrm{kg}^{-1} \mathrm{DM}\right)$} \\
\hline $\mathrm{C}$ & $6.75 a \pm 0.52$ & $40.8 \mathrm{a} \pm 3.82$ & $10.3 \mathrm{a} \pm 1.10$ & $1.01 \mathrm{a} \pm 0.01$ \\
\hline MF & $6.56 \mathrm{a} \pm 0.27$ & $45.0 \mathrm{a} \pm 1.69$ & $11.3 \mathrm{a} \pm 0.40$ & $1.19 \mathrm{ab} \pm 0.08$ \\
\hline WS & $6.48 \mathrm{a} \pm 0.04$ & $43.3 \mathrm{a} \pm 2.23$ & $11.3 \mathrm{ab} \pm 0.39$ & $1.24 \mathrm{ab} \pm 0.03$ \\
\hline WSB I & $6.32 \mathrm{a} \pm 0.08$ & $34.2 \mathrm{a} \pm 1.14$ & $9.89 \mathrm{a} \pm 0.26$ & $1.09 \mathrm{a} \pm 0.13$ \\
\hline WSB II & $6.47 \mathrm{a} \pm 0.22$ & $47.5 \mathrm{a} \pm 2.81$ & $12.2 \mathrm{ab} \pm 0.84$ & $1.29 \mathrm{ab} \pm 0.10$ \\
\hline MS & $6.40 \mathrm{a} \pm 0.15$ & $47.6 \mathrm{a} \pm 1.18$ & $11.1 \mathrm{ab} \pm 0.98$ & $1.22 \mathrm{ab} \pm 0.03$ \\
\hline MSB I & $6.38 \mathrm{a} \pm 0.15$ & $45.0 \mathrm{a} \pm 1.66$ & $10.6 \mathrm{ab} \pm 1.06$ & $1.20 \mathrm{ab} \pm 0.10$ \\
\hline MSB II & $6.50 \mathrm{a} \pm 0.19$ & $51.1 \mathrm{a} \pm 8.92$ & $15.3 b c \pm 0.66$ & $1.29 \mathrm{ab} \pm 0.25$ \\
\hline
\end{tabular}

Each value represents the mean of three replicates \pm standard deviation, mean values marked with the same letters in column do not differ significantly according to the Duncan test at $\mathrm{p} \leq 0.05$, factor - fertilisation.

decrease in $\mathrm{pH}$ compared to the soil $\mathrm{pH}$ before setting up the experiment, was determined in soils with $2.25 \mathrm{t} \mathrm{ha}^{-1}$ of WSB I, MBS I, and MS. The results of our study also confirm the findings of Houben et al. (2013), who discovered an increase in soil $\mathrm{pH}$ (by 0.8 unit), followed by the application of Miscanthus straw, only after introducing $90 \mathrm{t} \mathrm{ha}^{-1}$ of biochar. The authors reported no changes in soil $\mathrm{pH}$ after applying Miscanthus biochar in lower doses (30 and $60 \mathrm{t} \mathrm{ha}^{-1}$ ). Also Alburquerque et al. (2013) found that the application of wheat straw biochar in doses below $1 \%\left(30 \mathrm{t} \mathrm{ha}^{-1}\right)$ in slightly acidic soil did not affect its $\mathrm{pH}$. They observed a significant increase in the soil $\mathrm{pH}$ to the value of 8.5 only after applying a $225 \mathrm{t} \mathrm{ha}^{-1}$ dose of wheat straw biochar. However, Alburquerque et al. (2013) argued that the biochar applied by them in doses of over $30 \mathrm{tha}^{-1}$ had a negative effect on the crop yield due to significantly increased electrical conductivity. The doses of organic materials applied in this study did not significantly increase electrical conductivity (EC) compared to the parameter value determined in the MF treatment (Table 3). However, it was found that the EC values increased relative to the applied doses of wheat straw and Miscanthus straw biochars.

Greater variability was found in the contents of total carbon and nitrogen (Table 3). In the second year of the experiment, a statistically significant increase in the $\mathrm{C}_{\text {total }}$ (by 35\%), compared to the MF treatment, was determined in soil with $5 \mathrm{t} \mathrm{ha}^{-1}$ of Miscanthus straw biochar (MSB II). Reduced content of total carbon (by $12 \%$ in relation to the MF treatment) was observed only in soil with $2.25 \mathrm{t} \mathrm{ha}^{-1}$ of wheat straw biochar (WSB I). However, the application of organic materials to the soil contributed to an average increase in the content of $\mathrm{C}_{\text {total }}$ by $21 \%$ compared to the $\mathrm{C}_{\text {total }}$ content determined in soil before the experiment.
The highest content of nitrogen, compared to the MF treatment, was determined in soil amended with WS and MSB II. As reported by Kuzyakov et al. (2009), thermally unconverted plant biomass is much more prone to decomposition than the biochar obtained from it. The reason for it is the higher content of an easily decomposable fraction of organic matter $(\mathrm{OM})$, which is an easily assimilable source of nutrients for soil microorganisms. Usually, this leads to intensification of the biological activity of soil in the first few weeks after the application of straw and, in consequence, an increase in $\mathrm{CO}_{2}$ emission which, according to the tests conducted by Wu et al. (2013), may be even $77 \%$ for $0.5 \%$ of wheat straw added to the soil. Studies of Zavalloni et al. (2011) revealed that the loss of C consumed by microorganisms for respiration processes after the application of thermally unconverted wheat straw was almost 23 times higher $\left(0.68 \%\right.$ day $^{-1}$ of the added $\left.\mathrm{C}\right)$ than the $\mathrm{C}$ loss resulting from the application in soil of wheat straw biochar $\left(0.03 \%\right.$ day $^{-1}$ of the added $\left.\mathrm{C}\right)$. This suggests that much better (long-term) effects of $\mathrm{C}$ retention in soil can be obtained after the application of biochar containing mainly a hardly decomposable fraction of OM. In addition, due to the sorption of organic compounds on the biochar surface and ability to retain water (which is a medium transporting nutrients) in its pores, biochar causes a systematic increase in the population and activity of soil microorganisms (Alburquerque et al. 2013; Kuzyakov et al. 2009; MierzwaHersztek et al., 2016). Similarly, our results confirm that the highest content of carbon and nitrogen in the second year of the experiment was present in treatments WSB II and MSB II (Table 3). It was also found that $\mathrm{C}$ and $\mathrm{N}$ were mostly used by soil microorganisms in the soil with $2.25 \mathrm{t}$ $\mathrm{ha}^{-1}$ of wheat straw biochar. 
The enzymatic activity of soil is considered the most important indicator allowing monitoring of the effect of farming, agricultural practices, and the presence of contaminants on the soil condition (Oleszczuk et al., 2014). Enzymatic activity also reflects the indirect capability of contaminated soil of self-purification (Cui et al., 2013). Currently, there are several mechanisms known that can explain the increase in the enzymatic activity of soil fertilised with biochar. Firstly, electrostatic forces and hydrophobic properties make microorganisms present on the porous surface of biochar less leachable. Secondly, labile fractions of carbon contained in biochar may constitute readily available substrates for the population of microorganisms, and the alkalising effect of biochar may improve the circulation of nutrients (Paz-Ferreiro et al., 2014; Wu et al., 2013). Biochar may also contain harmful substances, such as heavy metals and PAHs and adversely affect the activity of soil microorganisms, including their enzymatic activity (Mierzwa-Hersztek et al. 2016; Oleszczuk et al., 2014; Wu et al., 2013). The study demonstrated that the addition of WS and MS before and after thermal conversion reduced the dehydrogenase activity (Fig. 1). A significant increase in the activity of DhA, compared to the soil with mineral fertilisation, was noted only in soils with the addition of wheat straw (9\%) and Miscanthus straw (7\%). Compared to the soil with mineral fertilisation, no significant effect in the dehydrohenase activity was observed in soil with the addition of wheat straw biochar and Miscanthus straw biochar in both doses. Wu et al. (2013) obtained similar results of DhA activity after the use of straw and straw biochar to these revealed in this study. The authors showed no effect of the application of wheat straw biochar into the soil in doses of 10 and $25 \mathrm{tha}^{-1}$ on the dehydrogenase activity, as well as a significant increase in the activity of the enzymes after the use of wheat straw in doses of 15 and $37.5 \mathrm{tha}^{-1}$. Probably, the differences in our results and the results obtained by Wu et al. (2013) may be due to the use of other parameters of the pyrolysis process $\left(450^{\circ} \mathrm{C}\right.$ and heating rate of $15^{\circ} \mathrm{C} \mathrm{min}^{-1}$ ) and several times higher doses of biochar and straw. On the other hand, Lehmann and Joseph (2015) argued that the addition of biochar into the soil in doses between 1 and $12 \mathrm{tha}^{-1}$ may reduce the production of some

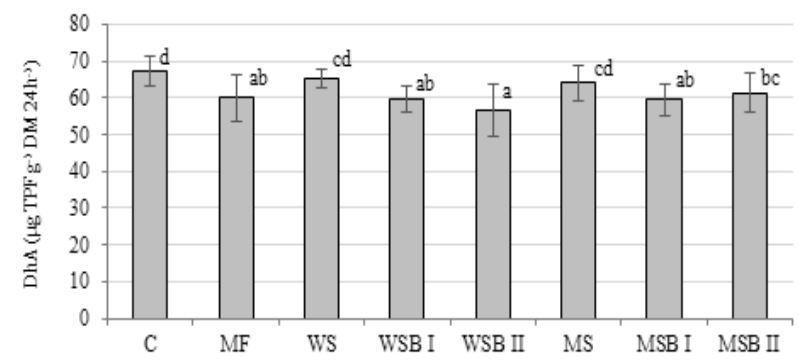

Fig. 1. Dehydrogenase activity of soils with addition of organic materials. Each value represents the mean of 9 replicates. Other explanations as in Table 1. enzymes involved in the mineralisation of organic matter. According to these authors, the reason for this may be the colonisation and growth of microorganisms on the biochar surface, which results, on the one hand, in increased mineralisation of organic matter, and on the other, in a reduced amount of substrates for the production of these enzymes.

Decomposition of organic materials in the soil, and thus their ability to immobilise $\mathrm{N}$, can also result in reduced emission of $\mathrm{N}_{2} \mathrm{O}$ into the atmosphere (Wu et al., 2013; Zavalloni et al., 2011). Ureases, whose activity is mainly related to the soil $\mathrm{pH}$ and structure, are considered as enzymes playing a key role in the transformation of $\mathrm{N}$. As reported by Yang et al. (2016), urease activity in the decomposition of organic materials, such as straw, is a result of the release of enzymes from cells of microorganisms decomposing plant cells, which are primarily bound to soil organic matter and clay minerals. The study showed that in most treatments, the application of organic materials to soil increased the activity of ureases (Fig. 2). Compared to the $\mathrm{C}$ treatment, a significant increase in the urease activity was observed in the soil with the addition of wheat straw (26\%) and Miscanthus straw biochar in doses of 2.25 and $5 \mathrm{t} \mathrm{ha}^{-1}$ (respectively by 25 and $40 \%$ ). However, compared to the MF treatment, the application of organic materials caused no significant $(p \leq 0.05)$ changes in Ure values. The lowest urease activity was determined in soil amended with $2.25 \mathrm{tha}^{-1}$ of wheat straw biochar in which also the smallest content of $\mathrm{C}$ and $\mathrm{N}$, and the lowest soil $\mathrm{pH}$ were observed (Table 2). Wu et al. (2013) obtained much lower urease activity than the one revealed in this study, since they used several times higher doses of wheat straw and wheat straw biochar. Wu et al. (2013) also reported that straw biochar and straw treatments reduced urease activities, compared to the control soil, and urease activities decreased with the increasing rate of biochar and straw additions. The results of our study show an opposite effect to the findings of $\mathrm{Wu}$ et al. (2013). In our study, Ure activities increased with the increasing rate of MSB and WSB additions.

Depending on the substrates used in the production of biochar and on the conditions of the pyrolysis process, the addition of biochar to soil may have a positive or negative impact on living organisms (Oleszczuk et al., 2014;

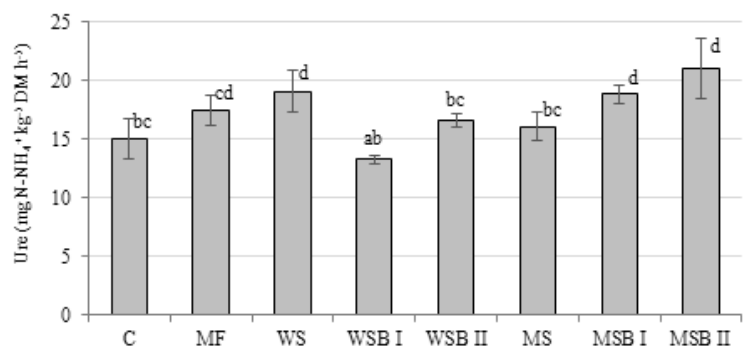

Fig. 2. Urease activity of soils with addition of organic materials. Each value represents the mean of 9 replicates. Other explanations as in Table 1. 
T a b 1 e 4. Toxicity to Vibrio fischeri and Heterocypris incongruens of soils with addition of organic materials

\begin{tabular}{lcc}
\hline & Vibrio fischeri & $\begin{array}{r}\text { Heterocypris } \\
\text { incongruens }\end{array}$ \\
\cline { 2 - 3 } Treatment & Percent effect (PE, \%) \\
\cline { 2 - 3 } Cuminescence inhibition & Growth inhibition \\
\hline C & $51 \mathrm{a} \pm 2.6$ & $34 \mathrm{ab} \pm 0.9$ \\
MF & $49 \mathrm{a} \pm 1.3$ & $42 \mathrm{~cd} \pm 6.1$ \\
WS & $60 \mathrm{bc} \pm 3.6$ & $32 \mathrm{a} \pm 5.3$ \\
WSB I & $59 \mathrm{bc} \pm 3.7$ & $39 \mathrm{bc} \pm 3.0$ \\
WSB II & $61 \mathrm{bc} \pm 1.5$ & $33 \mathrm{ab} \pm 0.9$ \\
MS & $57 \mathrm{~b} \pm 4.0$ & $32 \mathrm{ab} \pm 3.2$ \\
MSB I & $71 \mathrm{~d} \pm 3.3$ & $47 \mathrm{~d} \pm 5.8$ \\
MSB II & $52 \mathrm{~b} \pm 1.5$ & $32 \mathrm{ab} \pm 1.7$ \\
\hline
\end{tabular}

Explanations as in Table 1. Each value represents the mean of three replicates \pm standard deviation; mean values marked with the same letters in column do not differ significantly according to the Duncan test at $\mathrm{p} \leq 0.05$; factor: fertilisation $(\mathrm{n}=3$ ).

Mierzwa-Hersztek et al., 2016). Toxic factors may be not only biochar parameters, such as $\mathrm{pH}, \mathrm{EC}$, elemental composition, the presence of organic and inorganic contaminants, but also the result of their interactions with soil (Gondek et al., 2016; Oleszczuk et al., 2014). The response of organisms to potential contaminants in the soil depends on not only the properties of the material itself, but also the sensitivity of the tested organism. In our study, the wheat straw and Miscanthus straw amendments before and after thermal conversion were toxic $(50 \% \leq \mathrm{PE}<100 \%)$ to Vibrio fischeri and exhibited low toxicity $(20 \% \leq \mathrm{PE}<50 \%)$ to Heterocypris incongruens (Table 4). A significant increase in the inhibition of $V$. fischeri luminescence was determined in soils amended with both straws and biochars compared to the MF treatment. The most toxic to both organisms was soil amended with $2.25 \mathrm{t} \mathrm{ha}^{-1}$ of Miscanthus straw biochar. In the case of $H$. incongruens, a significant increase in toxicity was found also in soil with the mineral fertilisation. In none of the analysed treatments, mortality of $H$. incongruens was observed. Furthermore, no relation between the response of the tested organisms ( $V$. fischeri and $H$. incongruens) and the dose and type of the biochar applied was observed.

Many scientists emphasised the necessity to perform ecotoxicological tests of biochars before and after their application into soil in order to assess directly their effect on soil organisms (Lehmann and Joseph 2015, MierzwaHersztek et al., 2016; Oleszczuk et al., 2014). Kołtowski et al. (2016) reported that the ecotoxicity of soils depend on the parameters, type of biochar, contaminant source, and soil type. Nevertheless, the literature data on biochar effects on living organisms are inconsistent. A positive effect (Hale et al., 2013, Domene et al., 2015), a negative effect (Hale et al., 2013), and no effect (Domene et al., 2015) on living organisms have been observed. As reported by Hale et al. (2013) and Koltowski et al. (2016), the negative effect of biochar may result from the reduced bioavailability of water and nutrients, as well as from the presence of contaminants occurring in biochar and soil. Unfortunately, literature data on this subject are rather scarce and usually concern only the toxicity (Kołtowski et al., 2016) or phytotoxicity of biochar (Gondek and Mierzwa-Hersztek, 2017).

Many scientists who investigated the impact of the agricultural use of biochar derived from various types of biomass showed that biochar can be an excellent source of nutrients for plants and, in consequence, improve crop yielding (Lehman and Joseph, 2015). In the study, no statistically significant $(\mathrm{p} \leq 0.05)$ increase in the yield was obtained after the application of organic materials before and after thermal conversion (Fig. 3). The lowest average amount of biomass of the mixture of perennial grasses with red clover was obtained from the $\mathrm{C}$ treatment $(8.65 \mathrm{t} \mathrm{DM}$ $\left.\mathrm{ha}^{-1}\right)$. The application of WS and MS to the soil increased crop yielding by 5 and $3 \%$, respectively, compared to the amount of biomass obtained from the MF treatment. Application of wheat straw biochar and M. giganteus straw biochar in a dose of $5 \mathrm{t} \mathrm{DM} \mathrm{ha}{ }^{-1}$ contributed to an increase in the average amount of grass mixture biomass by 2 and $14 \%$, respectively, compared to the yield obtained from the soil with mineral fertilisation. According to Alburquerque et al. (2013), crop yielding is influenced by not so much the dose of biochar as the type of feedstock used in the production of biochar. By assessing the impact of 5 types of biochar (olive stone, almond shell, wheat straw, pine woodchips, and olive-tree pruning) introduced in 5 doses (15, $30,75,150$, and $225 \mathrm{tha}^{-1}$ ), the authors concluded that the addition of biochar at the same doses both increased and decreased the yield compared to the control. The importance of the type and dose of biochar for crop yielding is also confirmed by our studies.

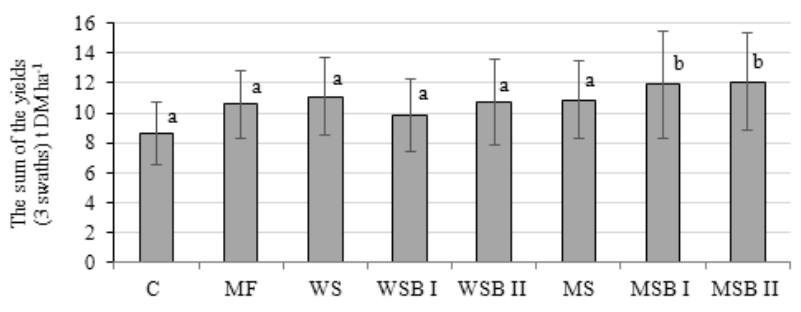

Fig. 3. Average yield of the mixture of perennial grass during the growing season 2015. Other explanations as in Table 1. 


\section{CONCLUSIONS}

1. The application of organic materials in different ways influenced the enzymatic activity, soil ecotoxicity, and plant growth.

2. The addition of biochar obtained from wheat straw and Miscanthus straw to the soil in amounts equivalent to 2.25 and $5 \mathrm{t} \mathrm{DM} \mathrm{ha}{ }^{-1}$ had no influence on dehydrogenase activity compared to the soil with mineral fertilisation. The organic materials applied, i.e. wheat straw and M. giganteus straw biochar in doses of $2.25 \mathrm{t}$ and $5 \mathrm{t} \mathrm{DM} \mathrm{ha}^{-1}$ caused positive effects on urease activity.

3. The biochar-amended soil was toxic to Vibrio fischeri and had low toxicity to Heterocypris incongruens.

4. Application of wheat straw biochar and M. giganteus straw biochar in doses of $5 \mathrm{t} \mathrm{DM} \mathrm{ha}^{-1}$ contributed to an increase in plant biomass production by 2 and 14\%, respectively, compared to the soil with mineral fertilisation.

5. Biochars had a more adverse effect on soil enzymatic activity and ecotoxicity to $H$. incongruens and $V$. fischeri than the non-converted wheat and $M$. giganteus straw, but significantly increased the grass crop yield.

Conflict of interest: The Authors do not declare conflict of interest.

\section{REFERENCES}

Alburquerque J.A., Calero1 J.M., Barrón V., Torrent J., del Campillo M.C., Gallardo A., and Villar R., 2013. Effects of biochars produced from different feedstocks on soil properties and sunflower growth. J. Plant Nutr. Soil Sci., $1-10$.

Ameloot N., Sleutel S., Das K.C., Kanagaratnam J., and De Neve S., 2015. Biochar amendment to soils with contrasting organic matter level: effects on $\mathrm{N}$ mineralization and biological soil properties. GCB Bioenergy, 7, 135-144.

Barret E.P., Joyner L.G., and Halenda P.H., 1951. The determination of pore volume and area distributions in porous substances. I. Computations from nitrogen isotherms. J. Amer. Chem. Soc., 73, 373-380.

Busch D., Stark A, Kammann C.I., and Glaser B. 2013. Genotoxic and phytotoxic risk assessment of fresh and treated hydrochar from hydrothermal carbonization compared to biochar from pyrolysis. Ecotox. Environ. Saf., 97, 59-66.

Casida L.E., Klein D.A., and Santoro T., 1964. Soil dehydrogenase activity. Soil Sci., 98, 371-376.

Cheng C.H., Lehmann J., Thies J.E., Burton S.D., and Engelhard M.H., 2006. Oxidation of black carbon by biotic and abiotic processes. Org. Geochem., 37, 1477-1488.

Cui H., Zhou J., Zhao Q., Si Y., Mao J., Fang G., and Liang J., 2013. Fractions of $\mathrm{Cu}, \mathrm{Cd}$, and enzyme activities in a contaminated soil as affected by applications of micro- and nanohydroxyapatite. J. Soils Sedim., 13,742-752.

Domene X., Enders A., Hanley K., and Lehmann J., 2015. Ecotoxicological characterization of biochars: role of feedstock and pyrolysis temperature. Sci. Total Environ., 512-513, 552-561.
Fekete I., Kotroczó Z., Varga C., Hargitai R., Townsend K., Csányi G., and Várbiró G., 2012. Variability of organic matter inputs affects soil moisture and soil biological parameters in a European detritus manipulation experiment. Ecosystems, 15, 792-803.

Gondek K., Baran A., and Kopeć M., 2014. The effect of lowtemperature transformation of mixtures of sewage sludge and plant materiale on content, leachability and toxicity of heavy metals. Chemosphere, 117, 33-39.

Gondek K. and Mierzwa-Hersztek M., 2017. The effect of thermal conversion of municipal sewage sludge on the content of $\mathrm{Cu}, \mathrm{Cd}, \mathrm{Pb}$ and $\mathrm{Zn}$ and phytotoxicity of biochars. J. Elem., 22(2), 427-435.

Gondek K., Mierzwa-Hersztek M., Baran A., Szostek M., Pieniążek R., Pieniążek M., Stanek-Tarkowska J., and Noga T., 2016. The effect of low-temperature conversion of plant materials on the chemical composition and ecotoxicity of biochars. Waste Biom. Val., 8, 599-609.

Hale S.E., Arp H.P.H., Kupryianchyk D., and Cornelissen G., 2016. A synthesis of parameters related to the binding of neutral organic compounds to charcoal. Chemosphere, 144, 65-74.

Houben D., Sonnet P., and Cornelis J-T., 2013. Biochar from Miscanthus: a potential silicon fertilizer. Plant Soil, DOI 10.1007/s11104-013-1885-8

IBI, 2014. International Biochar Initiative. Standardized Product Definition and Product Testing Guidelines for Biochar That is Used in Soil. Final Report. October. Report No. IBI-STD-2.0.

Jindo K., Suto K., Matsumoto K., Garcia C., Sonoki T., and Sanchez-Monedero M.A., 2012. Chemical and biochemical characterisation of biochar-blended composts prepared from poultry manure. Biores. Technol., 11, 396-404.

Kołtowski M., Hilber I., Bucheli T.D., and Oleszczuk P., 2016. Effect of steam activated biochar application to industrially contaminated soils on bioavailability of polycyclic aromatic hydrocarbons and ecotoxicity of soils. Sci. Tot. Environ., 566-567, 1023-1031.

Kuzyakov Y., Subbotina I., Chen H., Bogomolova I., and Xu X., 2009. Black carbon decomposition and incorporation into soil microbial biomass estimated by $14 \mathrm{C}$ labeling. Soil Biol. Bioch., 41, 210-219.

Lehmann J. and Joseph S., 2015 (Eds). Biochar for Environmental Management. Science, Technology and Implementation. Routledge, London, UK.

Lehmann J., Rillig M.C., Thies J., Masiello C.A., Hockaday W.C., and Crowley D., 2011. Biochar effects on soil biota - a review. Soil Biol. Bioch., 43(9), 1812-1836.

Lu H., Zhang W., Wang S., Zhuang L., Yang Y., and Qiu R., 2013. Characterization of sewage sludge-derived biochars from different feedstocks and pyrolysis temperatures. J. Anal. Appl. Pyrol., 102, 137-143.

MicrobicsCorporation, 1992. Microtox Manual Toxicity Testing Handbook. Carlsbad, CA, USA.

Mierzwa-Hersztek M., Gondek K., and Baran A., 2016. Effect of poultry litter biochar on soil enzymatic activity, ecotoxicity and plant growth. Appl. Soil Ecol., 105: 144-150.

Oleszczuk N., Castro J.T., da Silva M.M., Korn Md., Welz B., and Vale M.G., 2007. Method development for the determination of manganese, cobalt and copper in green coffee 
comparing direct solid sampling electrothermal atomic absorption spectrometry and inductively coupled plasma optical emission spectrometry. Talanta, 73(5), 862-869.

Oleszczuk P., Jośko I., Futa B., Pasieczna-Patkowska S., Pałys E., and Kraska P., 2014. Effect of pesticides on microorganisms, enzymatic activity and plant in biochar-amended soil. Geoderma, 214-215, 10-18.

Ostracodtoxkit F., 2001. Direct contact toxicity test for freshwater sediments. Standard operational procedure. Nazareth, Belgium, MicroBioTest Inc, 35.

Paz-Ferreiro J., Fu S., Méndez A., and Gascó G., 2014. Interactive effects of biochar and the earthworm Pontoscolex corethrurus on plant productivity and soil enzyme activities. J. Soils Sedim., 14(3), 483-494.

Schmidt M.W., Torn M.S., Abiven S., Dittmar T., Guggenberger G., Janssens I.A., Kleber M., KögelKnabner I., Lehmann J., Manning D.A.C., Nannipieri P., Rasse D.P., Weiner S., and Trumbore S.E., 2011. Persistence of soil organic matter as an ecosystem property. Nature, 478(7367), 49-56.

Song W. and Guo M., 2012. Quality variations of poultry litter biochar generated at different pyrolysis temperatures. J. Anal. Appl. Pyrol., 94, 138-145.

Sun Y., Gao B., Yao Y., Fang J., Zhang M., Zhou Y., Chen H., and Yang L., 2014. Effects of feedstock type, production method, and pyrolysis temperature on biochar and hydrochar properties. Chemical Eng. J., 240, 574-578.

WRB, 2015. World reference base for soil resources. International soil classification system for naming soils and creating legends for soil maps. Food and Agriculture Organization of the United Nations, Rome, 1-203.

Wu F., Jia Z., Wang S., Chang S.X., and Startsev A., 2013. Contrasting effects of wheat straw and its biochar on greenhouse gas emissions and enzyme activities in a Chernozemic soil. Biol. Fertil. Soils, 49, 555-565.

Yang X., Liu J., McGrouther K., Huang H., Lu K., Guo X., He L., Lin X., Che L., Ye Z., and Wang H., 2016. Effect of biochar on the extractability of heavy metals $(\mathrm{Cd}, \mathrm{Cu}, \mathrm{Pb}$, and $\mathrm{Zn}$ ) and enzyme activity in soil. Environ. Sci. Poll. Res., 23(2), 974-984.

Zantua M.I. and Bremner J.M., 1975. Comparison of methods of assaying urease activity in soils. Soil Biol. Biochem., 7, 291-295.

Zavalloni C., Alberti G., Biasiol S., Vedove G.D., Fornasier F., Liu J., and Peressotti A., 2011. Microbial mineralization of biochar and wheat straw mixture in soil: A short-term study. Appl. Soil Ecolol., 50, 45-51.

Zhang J., Chen G., Sun H., Zhou S., and Zou G., 2016. Straw biochar hastens organic matter degradation and produces nutrient-rich compost. Biores. Technol., 200, 876-883. 